\title{
Analisis Kemampuan Penalaran Ilmiah pada Pembelajaran Interactive Demonstration disertai Formative Assessment
}

\author{
Demara Balqis $^{1}$, Sentot Kusairi ${ }^{1}$, Edi Supriana ${ }^{1}$ \\ ${ }^{1}$ Pendidikan Fisika-Universitas Negeri Malang
}

\begin{tabular}{l}
\hline \hline INFO ARTIKEL \\
\hline Riwayat Artikel: \\
Diterima: 15-05-2019 \\
Disetujui: $13-11-2019$ \\
\hline
\end{tabular}

Kata kunci:

scientific reasoning; interactive demonstration; formative assessment; penalaran ilmiah; interactive demonstration; formative assessment

\begin{abstract}
ABSTRAK
Abstract: This research aims to analyze the students scientific reasoning ability in physics learning. The sample was 32 students of $10^{\text {th }}$ grade in Public Senior High School 7 Malang. The instrument test is two tiers with 13 questions. The result shows that there are differences between students scientific reasoning score before and after interactive demonstration learning with formative assessment. In pretest, the students scientific reasoning scores were low, 25 students were at level of concrete reasoning and 9 students were at initial transition level. When the posttest, scientific reasoning score has increased, 10 students at concrete reasoning level, 15 students at the initial transition level, 8 students are at final transition level, and 1 student reach the level at formal reasoning level. Teacher need to give the innovative learning strategies that can improve student's scientific reasoning.
\end{abstract}

\begin{abstract}
Abstrak: Penelitian ini bertujuan untuk mengetahui kemampuan penalaran ilmiah siswa pada pembelajaran interactive demonstration disertai formative assessment. Sampel yang digunakan yaitu 34 siswa pada kelas X IPA di SMA Negeri 7 Malang. Instrumen yang digunakan berupa tes Two Tiers dengan 13 pertanyaan. Hasil penelitan menunjukkan bahwa terdapat perbedaan antara penalaran ilmiah siswa sebelum dan setelah dilakukan pembelajaran interactive demonstration disertai formative assessment. Pada saat pretest skor penalaran ilmiah siswa rendah yaitu 25 siswa berada pada tingkat penalaran konkret dan sembilan siswa berada pada tingkat transisi awal. Saat posttest skor penalaran ilmiah mengalami peningkatan yaitu 10 siswa pada tingkat penalar konkret, 15 siswa pada tingkat transisi awal, 8 siswa berada tingkat transisi akhir hingga ada seorang yang mencapai tingkat penalaran formal. Guru perlu memberikan strategi pembelajaran inovatif yang dapat memperbaiki penalaran ilmiah siswa.
\end{abstract}

\section{Alamat Korespondensi:}

Demara Balqis

Pendidikan Fisika

Universitas Negeri Malang

Jalan Semarang 5 Malang

E-mail: demara_balqis @yahoo.com

Kemampuan penalaran ilmiah adalah kemampuan yang penting dimiliki dalam mempelajari fisika. Hal ini karena fisika mempelajari fenomena alam secara ilmiah dan menjelaskan gejala alam serta keteraturan hukum alam melalui proses penalaran ilmiah (Bao et al, 2009; Mooroe et al, 2011). Kemampuan penalaran ilmiah memengaruhi hasil belajar sains (Nahru \& Syarkowi, 2017). Penalaran ilmiah yang tinggi berdampak pada implikasi edukasi yang penting (Utama \& Syarkowi, 2018). Kemampuan penalaran ilmiah penting untuk siswa dalam menyelesaikan masalah dalam suatu pembelajaran karena kemampuan ini terkait dengan pemahaman tentang konsep utama sains dan selanjutnya agar dapat mengkomunikasikan pemahamannya kepada orang lain (Lawson, 2004). Kemampuan scientific reasoning yang tinggi membuat siswa dapat memecahkan masalah pada situasi yang baru, selain itu dapat merancang penyelidikan untuk menyelesaikan masalah yang ada (Bao dkk, 2009). Keterampilan penalaran ilmiah mencakup keterampilan kognitif pada aspek konseptual dan prosedural melalui aktivitas penyelidikan ilmiah, seperti memprediksi, mengajukan pertanyaan, mengamati, mengukur, melakukan percobaan, menginterpretasi data, mengevaluasi bukti, merumuskuan teori atau model (Zimmerman, 2000).

Meskipun kemampuan penalaran ilmiah penting, guru belum memperhatikan kemampuan ini. Hal ini terlihat dari rendahnya skor pada hasil tes penalaran ilmiah yang diberikan pada saat studi pendahuluan dan pada pretest. Berdasarkan observasi yang dilaksanakan di SMA Negeri 7 Malang, siswa berpendapat bahwa fisika selalu menghapal rumus dan terkait perhitungan matematis, Dalam studi PISA tahun 2015 di bidang sains Indonesia memperoleh skor 403. Dibandingkan dengan skor rata-rata yang ditetapkaan oleh OECD, yaitu 501, maka dapat disimpulkan bahwa penalaran ilmiah siswa masih rendah dan butuh peningkatan (OECD, 2015). 
Berdasarkan hal tersebut kemampuan penalaran ilmiah perlu dilatihkan dalam pembelajaran fisika. Faktor yang memengaruhi penalaran ilmiah antara lain adalah proses pembelajaran, kebiasaan belajar, usia, dan pengalaman belajar (Acido, Tella dkk, 2008). Beberapa penelitian sebelumnya mendapatkan bahwa penalaran ilmiah siswa dengan pembelajaran interactive demonstration lebih baik dibandingkan menggunakan pembelajaran konvensional (Slekiene \& Reguliene, 2010). Pembelajaran berpusat pada guru dan hanya bertujuan untuk mentransfer pengetahuan. Maka dari itu, pembelajaran perlu disertai formative assessment untuk memantau pemahaman siswa. Adanya feedback pada formative assessment membantu guru memahami cara berpikir peserta didik, dengan begitu guru memilih lebih banyak strategi efektif untuk membantu peserta didik bergerak ke arah pemahaman konseptual yang lebih dalam sesuai tujuan pembelajaran (Gayle, 2009).

Berdasarkan uraian yang telah disampaikan terkait rendahnya penalaran ilmiah siswa dan pentingnya meningkatkan penalaran ilmiah bagi siswa melalui proses pembelajaran, maka penelitian ini bertujuan untuk menganalisis bagaimana penalaran ilmiah siswa sebelum dan setelah dilakukan pembelajaran interactive demonstration disertai formative assessment.

\section{METODE}

Penelitian ini menggunakan metode mixed methods dengan desain embedded experimental model. Tahapan pelaksanaan penelitian ini menggunakan pendekatan kuantitatif dan kualitatif (Cresswell, 2017). Sampel penelitian ini adalah 34 siswa kelas X SMA Negeri 7 Malang. Penelitian dilakukan mulai bulan Maret sampai dengan April 2018.

Instrumen penelitian yaitu Rencana Pelaksanaan Pembelajaran (RPP), Lembar Kerja Siswa (LKS), lembar observasi, instrumen tes penalaran ilmiah. RPP pembelajaran interactive demonstration disertai formative assessment memiliki lima tahap. Dimana dalam setiap tahapan pembelajaran disertai dengan formative assessment. Tahap pembelajaran (Wenning, 2011) ditunjukkan pada tabel 1 .

\section{Tabel 1. Tahapan Pembelajaran Interactive Demonstration}

Tahapan Kegiatan Pembelajaran

\footnotetext{
1. Observation Siswa memperhatikan penjelasan demonstrasi yang dilakukan oleh guru. Peserta didik membuat prediksi dan menjelaskan terkait demonstrasi yang akan dilakukan

2. Manipulation Siswa atau guru melaksanakan dan memperhatikan demonstrasi. Kemudian siswa membandingkan hasil demonstrasi dengan prediksi yang telah dibuat

3. Generalization Kemudian peserta didik berdiskusi untuk membuat kesimpulan awal dengan mengkonstruk konsep, prinsip atau hukum yang terkait dengan demonstrasi

4. Verification Peserta didik memodelkan berdasarkan pada hukum atau prinsip yang telah dibuat pada tahap generalisasi, dan mempresentasikan hasil diskusi

5. Application Peserta didik menarik kesimpulan yang kemudian diterapkan pada konsep baru yang masih berkaitan dengan konsep yang dibahas, yaitu mengerjakan latihan soal
}

Instrumen tes pengukuran penalaran ilmiah terdiri dari 13 soal pilihan ganda bertingkat (two tiers). Terdapat enam indikator dalam penalaran ilmiah. Persebaran soal berdasarkan indikator penalaran ilmiah ditunjukkan pada tabel 2.

Tabel 2. Persebaran Soal Berdasarkan Indikator Penalaran Ilmiah

\begin{tabular}{ll}
\hline Indikator Penalaran Ilmiah & Nomor Soal \\
\hline Konservasi massa dan volume & 1,2 \\
Penalaran proporsional & 3,4 \\
Mengontrol variabel & $5,6,7$ \\
Penalaran probabilistik & 8,9 \\
Penalaran korelasi & 10 \\
Penalaran hipotesis-deduktif & $11,12,13$
\end{tabular}

Analisis kuantitatif digunakan untuk mengetahui pengaruh pembelajran interactive demonstration yang disertai formative assessment terhadap penalaran ilmiah siswa. Setelah melakukan uji normalitas dan homogenitas pada hasil pretest dan posttest siswa, kemudian dilakukan uji beda. Data dikatakan terdistribusi normal apabila nilai signikansi uji $\alpha<0,05$. Data homogen apabila nilai signifikansi uji $\alpha>0,05$. Apabila seluruh data normal dan homogen, maka dapat menggunakan paired sample t-test. Apabila terdapat data yang tidak normal atau tidak homogen, maka menggunakan uji beda non parametrik uji Wilcoxon. Langkah berikutnya apabila terdapat perbedaan skor penalaran ilmiah sebelum dan sesudah intervensi pembelajaran dilakukan perhitungan $N$-gain. Ketentuan tingkat kategori nilai $N$-gain (Hake, 1998) ditunjukkan pada tabel 3. 
Tabel 3. Kategori nilai $N$-gain

\begin{tabular}{cc}
\hline Rentang & Kategori \\
\hline$\langle g\rangle \geq 0,7$ & Tinggi \\
$0,7\rangle\langle g\rangle \geq 0,3$ & Sedang \\
$\langle g\rangle\langle 0,3$ & Rendah \\
\hline
\end{tabular}

Kemudian dilakukan uji effect size untuk mengetahui seberapa besar pengaruh model pembelajaran interactive demonstration disertai formative assessment terhadap penalaran ilmiah. Kategori kekuatan efek menggunakan Cohen's effect (Cohen, 2007). Kategori effect size ditunjukkan pada tabel 4.

Tabel 4. Kategori Effect Size

\begin{tabular}{ll}
\hline Rentang & Kategori \\
\hline$>1,00$ & Kuat (Strong Effect) \\
$0,51-1,00$ & Sedang (Moderate Effect) \\
$0,21-0,50$ & Cukup (Modest Effect) \\
$0,00-0,20$ & Lemah (Weak Effect) \\
\hline
\end{tabular}

Pada pengukuran penalaran ilmiah digunakan instrumen tes pilihan ganda beralasan yaitu Lawsons Classroom Test Scientific Reasoning (LCTSR) (Lawon, 2004). Untuk mengetahui kategori penalaran ilmiah siswa menggunakan pedoman yang ditunjukkan pada tabel 5.

Tabel 5. Kategori Penalaran Ilmiah

\begin{tabular}{ll}
\hline Kategori & Rentang \\
\hline Penalar konkret & $0-4$ \\
Transisi awal & $5-7$ \\
Transisi akhir & $8-10$ \\
Penalar formal & $11-13$ \\
\hline
\end{tabular}

Langkah berikutnya yaitu melakukan analisis setiap aspek penalaran ilmiah siswa berdasarkan hasil pretest dan posttest. Selain itu, menganalisis perubahan jawaban setiap butir soal dari pretest ke posttest. Berdasarkan analisis setiap butir soal kemudian menganalisis soal yang memiliki jawaban benar dengan persentase tertinggi dan terendah.

\section{HASIL}

Deskripsi hasil pretest dan posttest penalaran ilmiah pada 34 siswa pada soal Lawsons Classroom Test Scientific Reasoning (LCTSR) disajikan pada tabel 6.

Tabel 6. Deskripsi Hasil Skor Pretest dan Posttest Penalaran Ilmiah

\begin{tabular}{lcccccc}
\hline & N & Minimum & Maximum & Mean & Std. Deviation & Skewness \\
\hline Pretest & 34 & 0 & 7 & 3,74 & 1,355 & $-0,029$ \\
Posttest & 34 & 2 & 11 & 6,12 & 2,143 & 0,074 \\
\hline
\end{tabular}

Berdasarkan hasil analisis diketahui terdapat perbedaan antara penalaran ilmiah siswa sebelum dan setelah dilakukan pembelajaran interactive demonstration disertai formative assessment. Terlihat skor minimum dan maksimum mengalami peningkatan dari pretest ke posttest. Skor rata-rata siswa pada saat pretest adalah 3,74, ini menunjukkan tingkat scientific reasoning awal yang dimiliki siswa yaitu tingkat penalar konkret. Skor rata-rata siswa pada posttest adalah 6,12 yang termasuk tingkat transisi awal. Terdapat peningkatan setelah pembelajaran diterapkan, hal ini dibuktikan dengan nilai rata-rata $\mathrm{N}$-gain sebesar 0,34 yang termasuk pada kategori sedang. Berdasarkan hasil uji beda Wilcoxon didapatkan nilai signifikansi sebesar 0,000 dimana nilai signifikansi kurang dari 0,05 menunjukkan adanya perbedaan penalaran ilmiah yang signifikan antara skor pretest dan posttest. Nilai effect size didapatkan sebesar $-0,75$ menunjukkan bahwa pengaruh pembelajaran interactive demonstration disertai formative assessment terhadap penalaran ilmiah siswa termasuk dalam kategori sedang.

Kategori penalaran ilmiah dibagi menjadi empat tingkat. Siswa dengan skor $0-4$ termasuk tingkat penalar konkret, skor 5-7 termasuk tingkat transisi awal, skor 8-10 termasuk tingkat transisi akhir, dan skor $11-13$ termasuk tingkat penalar formal (Lawson, 2004). Tingkat penalaran ilmiah siswa berdasarkan hasil tes disajikan pada tabel 7. 
Tabel 7. Tingkat Penalaran Ilmiah Siswa

\begin{tabular}{lcc}
\hline & Pretest & Posttest \\
\hline Penalar konkret & 25 & 10 \\
Transisi awal & 9 & 15 \\
Transisi akhir & 0 & 8 \\
Penalar formal & 0 & 1 \\
\hline Total & 34 & 34 \\
\hline
\end{tabular}

Berdasarkan tabel 7 setelah pembelajaran interactive demonstration disertai formative assessment dilakukan saat pretest siswa yang berada pada tingkat penalar konkret sebanyak 25 siswa, kemudian pada saat posttest menjadi 10 siswa. Tingkat penalaran ilmiah siswa mengalami peningkatan, sebelumnya pada pretest tingkat transisi awal dari sembilan siswa meningkat menjadi 15 siswa. Delapan siswa berada tingkat transisi akhir hingga ada satu siswa yang berada pada tingkat penalar formal. Persentase siswa yang menjawab benar pada setiap aspek disajikan dalam bentuk grafik. Berikut grafik persenatse perubahan jawaban benar setiap butir soal dari pretest ke posttest disajikan pada gambar 1.

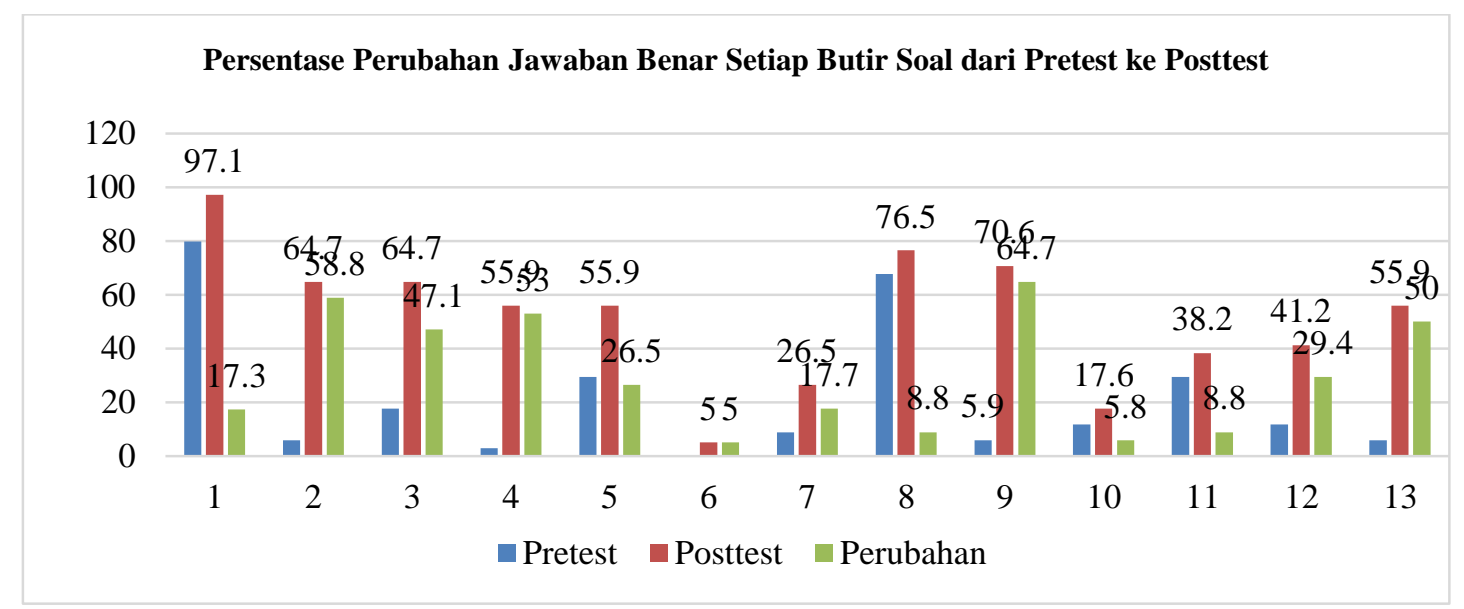

Gambar 1. Grafik Persentase Perubahan Jawaban Benar Setiap Butir Soal dari Pretest ke Posttest

\section{PEMBAHASAN}

Berdasarkan hasil penelitian terdapat peningkatan penalaran ilmiah siswa sebelum dan setelah dilakukan pembelajaran interactive demonstration disertai formative assessment. Terlihat skor minimum dan maksimum mengalami peningkatan dari pretest ke posttest. Skor rata-rata siswa pada saat pretest adalah 3,74, ini menunjukkan tingkat scientific reasoning awal yang dimiliki siswa yaitu tingkat penalar konkret. Pada saat posttest skor rata-rata adalah 6,12 yang termasuk dalam tingkat transisi awal dimana siswa dapat mengategorikan pendapat untuk memutuskan apa yang akan dilakukan, namun tetap membutuhkan model yang konkret sesuai hasil percobaan. Setelah pembelajaran interactive demonstration disertai formative assessment dilakukan saat pretest siswa yang berada pada tingkat penalar konkret sebanyak 25 siswa, kemudian pada saat posttest menjadi 10 siswa. Tingkat penalaran ilmiah siswa mengalami peningkatan, sebelumnya pada pretest tingkat transisi awal dari sembilan siswa meningkat menjadi 15 siswa. Sebelum pembelajaran tidak terdapat siswa pada tingkat transisi akhir dan penalaran formal. Setelah diberikan pembelajaran, pada saat posttest didapatkan delapan siswa berada tingkat transisi akhir hingga ada satu siswa yang berada pada tingkat penalar formal. Persentase seluruh aspek penalaran ilmiah pada saat posttest lebih tinggi dibandingkan saat pretest. Setelah pembelajaran berlangsung dan dilakukan posttest terlihat aspek yang memiliki jawaban benar dengan persentase tertinggi adalah aspek conservation of massa and volume dan persentase terendah adalah aspek correlational reasoning. Aspek conservation of massa and volume disajikan pada soal nomor 1 dan 2 . Aspek correlational reasoning disajikan pada soal nomor 10 .

Peningkatan skor penalaran ilmiah dapat terjadi karena dalam interactive demonstration terjadi interaksi antara guru dan siswa yang memberi peluang siswa untuk berpikir lebih aktif ketika prediksi yang dibuat tidak sama dengan hasil pengamatan. Selain itu, siswa tidak hanya diam dan mendengarkan guru, namun ikut berperan aktif ketika mengamati dan melakukan demonstrasi. Pada tahap observation siswa diminta membuat prediksi sebelum demonstrasi dilakukan, hal ini dapat mengasah proses bernalar siswa (Tytler, 2007). Pada tahap manipulation dan verification siswa melakukan proses bernalar pada saat melakukan demonstrasi dan percobaan untuk mendapatkan data yang sesuai dengan tujuan pembelajaran (Furtak et al, 2010). Selanjutnya, pada tahap generalization siswa membandingkan hasil demonstrasi dengan prediksi yang telah dibuat. Kemudian peserta didik mengonstruk konsep, prinsip atau hukum yang dibutuhkan untuk menjelaskan demonstrasi tersebut 
melalui diskusi. Dalam tahap ini scientific reasoning dapat meningkat pada saat mengumpulkan dan menganalisis data (Furtak et al, 2010). Kemudian siswa mendapatkan konsep yang baru (Al Khawaldeh, 2013). Selanjutnya, pada tahap application dimana siswa melakukan kegiatan "it's time to teach" juga dapat meningkatkan scientific reasoning siswa (Chin \& Teou, 2009). Pada tahap application ini diberikan penilaian formatif berupa soal check point, pemberian soal ini mengasah scientific reasoning siswa (Bybee et al, 2006).

Hasil penelitian ini sesuai dengan penelitian sebelumnya, yaitu faktor yang memengaruhi penalaran ilmiah, seperti proses pembelajaran, kebiasaan belajar, usia, dan pengalaman belajar (Tella, 2008). Pembelajaran interactive demonstration merupakan level of inquiry tahap kedua yang dikembangkan oleh Wenning (Wenning, 2010). Keterampilan penalaran ilmiah dapat dikembangkan melalui pembelajaran berbasis inkuiri (Tella, 2008). Penelitian lain menunjukkan pembelajaran berbasis inkuiri membuat penalaran ilmiah siswa lebih baik karena siswa dilatih membuat prediksi, menjelaskan, melakukan penyelidikan, dan memecahkan masalah (Shofiyah, 2013). Selain itu, kemampuan penalaran ilmiah siswa dapat mengalami peningkatan dengan penerapan formative assessment pada pembelajaran tertentu (Etkina et al, 2009).

Berdasarkan hasil penelitian guru harus memberikan pembelajaran yang dapat meningkatkan penalaran ilmiah siswa, salah satu cara yaitu dengan menerapkan pembelajaran interactive demonstration disertai formative assessment. Interative demonstration dapat diterapkan dalam pembelajaran fisika dengan bantuan teknologi seperti video analysis untuk membantu guru saat menjelaskan demonstrasi pada materi yang tergolong abstrak. Siswa perlu diberikan contoh soal dan latihan soal yang kontekstual untuk mengembangkan penalaran ilmiah siswa sehingga pengetahuan yang dimiliki dapat dimanfaatkan untuk memecahkan masalah dalam kehidupan sehari-hari.

\section{SIMPULAN}

Terdapat perbedaan scientific reasoning siswa sebelum dan sesudah melaksanakan pembelajaran interactive demonstration disertai formative assessment. Scientific reasoning siswa mengalami peningkatan, hal ini dibuktikan melalui nilai $\mathrm{N}$-Gain sebesar 0,34 yang termasuk dalam kategori sedang. Pengaruh pembelajaran interactive demonstration disertai formative assessment terhadap scientific reasoning dapat dilihat melalui nilai effect size yaitu sebesar 0,75 yang termasuk dalam kategori sedang. Pada saat pretest $73,5 \%$ siswa memiliki tingkat penalar konkret dan $26,5 \%$ siswa memiliki tingkat transisi awal. Pada saat posttest tingkat penalaran siswa mengalami peningkatan menjadi $29,4 \%$ siswa pada tingkat penalar konkret, $44,1 \%$ pada transisi awal, 23,5\% siswa pada transisi akhir, dan 2,9\% siswa hingga mencapai tingkat penalar formal.

Hasil penelitian yang didapatkan masih perlu disempurnakan karena adanya keterbatasan peneliti untuk melakukan penelitian dengan sampel yang lebih banyak dan waktu pemberian intervensi pembelajaran yang lebih lama. Disarankan pada penelitian selanjutnya yang akan menggunakan pembelajaran interactive demonstration khususnya pada tahap application guru memberikan kuis yang kontekstual sehingga dapat mengasah penalaran ilmiah siswa dengan menerapkan pengetahuan yang telah didapatkan selama pembelajaran untuk memecahkan kasus lain.

\section{DAFTAR RUJUKAN}

Al Khawaldeh. S. A. (2013). Prediction/Discussion-Based Learning Cycle Versus Conceptual Change Text: Comparative Effects on Students' Understanding of Genetics. Research in Science \& Technological Education, 31(2), 168—183.

Bao, et.al. (2009). Learning and Scientific Reasoning. Science Education Forum, 323, 586-587.

Bybee, R. W., Taylor, J. A., Gardner, A., Van Scotter, P., Powell, J. C., Westbrook, A. \& Landes, N. (2006). The BSCS 5E Instructional Model: Origins an Effectiveness. Colorado Springs. Co: BSCS, 5, 88-98.

Chin, C., \& Teou, L. Y. (2009). Using Concept Cartoons in Formative Assessment: Scaffolding Students' Argumentation. International Journal of Science Education, 31(10), 1307-1332.

Cohen. L., Manion, L., \& Morrison, K. (2007). Reseach Methods in Education Sixth Edition. Newyork: Taylor \& Francis eLibrary.

Creswell, J.W. \& Clark, V. L. P. (2007). Designing and Conducting Mixed Methods Research. United States of Amerika: Sage Publications, Inc.

Etkina, E., Karelina, A., Murthy, S., \& Maria Ruibal-Villasenor. (2009). Using Action Research to Improve Learning and Formative Assessment to Conduct Research. Physical Review Special Topics - Physics Education Research 5, 010109.

Furtak, E. M., Hardy, I., Beinbrech, C., Shavelson, R. J., \& Shemwell, J. T. (2010). A Framework for Analysing EvidenceBased Reasoning in Science Classroom Discourse. Educational Assessment, 15(3-4), 175-196.

Gayle A. Buck., \& Amy E. Trauth-Nare. (2009). Preparing Teachers to Make the Formative Assessment Process Integral to Science Teaching and Learning. Journal of Science Teacher Education, 20(5), 475-494

Hake, R. R. (1998). Interactive-Engagement Versus Traditional Methods: A Six Thousand-Student Survey of Mechanics Test Data for Introductory Physics Courses. American Journal of Physics, 66(1), 64-75.

Lawson, A. E. (2004). The Nature and Development of Scientific Reasoning: A Synthetic View. International Journal of Science and Mathematics Education, 23, 307.

OECD. (2015). PISA 2012 Results in Focus What 15-Year-Olds Know and What They Can Do with What They Know. (Online), (http://www.oecd-ilibrary.org), diakses tanggal 1 Mei 2018. 
Nehru, N. \& Syarkowi, A. (2017). Analisis Desain Pembelajaran untuk Meningkatkan Literasi Sains Berdasarkan Profil Penalaran Ilmiah. WAPFI (Wahana Pendidikan Fisika), 2(1), 20-24.

Shofiyah, N., Supardi, Z. A. I., \& Jatmiko, B. (2013). Mengembangkan Penalaran Ilmiah (Scientific Reasoning) Siswa melalui Model Pembelajaran 5E pada Siswa Kelas X SMAN 15 Surabaya. Jurnal Pendidikan IPA Indonesia, 2(1), 83 -87.

Tella, A. (2008). Teacher Variables as Predictors of Academic Achievement of Primary School Pupils Mathematics. International Electronic Journal of Elementary Education, 1(1).

Tytler, R. (2007). Re-Imagining Science Education Engaging Students in Science for Australia's Future. Australia: ACER.

Wenning, C. J. (2010). Levels of Inquiry: Using Inquiry Spectrum Learning Sequences to Teach Science. Journal of Physics Teacher Education Online, 5(4), 11-19. 